Anna Kuśmirek

Uniwersytet Kardynała Stefana Wyszyńskiego, Warszawa akusmirek22@gmail.com

ORCID 0000-0002-1736-9897

DOI: http://dx.doi.org/10.12775/BPTh.2021.020
Biblica

et

Patristica

Thoruniensia
14 (2021) 4: 383-399

ISSN (print) 1689-5150

ISSN (online) 2450-7059

\title{
Prorok Salomon i jego proroctwa w Targumie Koheleta
}

\section{The Prophet Solomon and His Prophecies in The Targum of Qoheleth}

\begin{abstract}
The The teachings in the Book of Qoheleth were too different and radical to be transmitted in the Jewish tradition without any corrections, reservations, modifications, or at least without a limited trust. One of the attempts at making its text more acceptable consisted in attributing the Book of Qoheleth to Solomon so that it could have been included in the canon of the Hebrew Bible. Testimonies of earlier interpretation of this Book have been present in its ancient translations, among others, in the Targum of Qoheleth (Tg Qoh). This article offers the analysis of those fragments of the Aramaic version of Qoheleth, which reflect the prophetic tradition of Solomon. The Targum rendering made the message of this biblical book to have gained a new meaning and contributed to strengthening the necessary acceptance of the book in rabbinic Judaism. The study also demonstrates to what extent the Targum has changed the original text of the Book of Qohelet.
\end{abstract}

Streszczenie. Nauki zawarte w Księdze Koheleta były zbyt odmienne i radykalne, by mogły być przekazywane w tradycji żydowskiej bez sprostowań, zastrzeżeń i modyfikacji, a przynajmniej z ograniczonym zaufaniem. Jednym z tych zabiegów było przypisanie autorstwa Księgi Koheleta Salomonowi po to, by mogła zostać włączona do kanonu Biblii Hebrajskiej. Świadectwa wczesnej interpretacji tej księgi są obecne w jej starożytnych przekładach, między innymi Targumie Koheleta (Tg Koh). Artykuł podejmuje analizę tych fragmentów wersji aramejskiej Koheleta, w których jest zawarta tradycja o Salomonie jako proroku. Przekaz biblijny zyskuje w ten sposób nowe znaczenie oraz wzmacnia potrzebną akceptację w judaizmie rabinicznym. Ponadto ukazuje, w jakim stopniu targum zmieniał oryginalny tekst biblijny.

Keywords: Qoheleth; Ecclesiastes; Solomon; targum; aramaic translation; Jewish interpretation.

Słowa kluczowe: Kohelet; Eklezjastes; Salomon; przekłady aramejskie; żydowska interpretacja. 
Księga Koheleta od początku stanowiła jedno z ciekawszych wyzwań hermeneutycznych Biblii Hebrajskiej. Najstarsze próby interpretacji można znaleźć już w samym tekście biblijnym, o czym świadczy pobożny epilog, który wyszedł spod ręki redaktora $(12,12-14)$. Ocena tej księgi w kręgach rabinicznych była sprawą sporną. Niektórzy z rabinów (np. Rabbi Akiba) uznawali jej autorytet. Inni natomiast wysuwali zastrzeżenia wobec jej wartości, wskazując na fragmenty stojące w sprzeczności z przekazem ortodoksyjnej wiary żydowskiej. Ostatecznie księga została włączona przez rabinów do kanonu żydowskiego i należy do trzeciego zbioru Biblii Hebrajskiej ( $\left.K^{e} t u ̂ b i ̂ m\right)$. Argumentem przeważającym była prawdopodobnie tradycja przypisująca autorstwo księgi królowi Salomonowi ${ }^{1}$. Rabini nadal jednak mieli zastrzeżenia do tego dzieła, o czym świadczą następujące słowa: „Mędrcy starali się zbojkotować Księgę Koheleta, ponieważ jej słowa są wzajemnie sprzeczne” (b. Shab. 30b) ${ }^{2}$. W podobnym duchu wypowiada się midrasz: „Mędrcy starali się zbojkotować Koheleta, ponieważ znaleźli w nim rzeczy prowadzące do odstępstwa” (KohR 1; zob. np. 2,24). Rabini postrzegali bowiem niektóre stwierdzenia Księgi Koheleta jako sprzeczne z przekazem Tory ${ }^{3}$. Paradoksalny i obrazowy język dzieła, mógł być odbierany jako kwestionujący panujące normy i realia społeczne, dlatego też rabini dokonywali różnych zmian w treści księgi, które we współczesnych badaniach określono mianem „przepracowania”4.

Świadectwa tego rodzaju zabiegów przekazuje zarówno literatura rabiniczna, jak i aramejska wersja Księgi Koheleta ${ }^{5}$. Podobnie jak inne targumy, jest to tłumaczenie parafrazujące, które łączy przekład z interpretacją. Targum Koheleta (Tg Koh) podaje bowiem obok prostych tłumaczeń tekstu hebrajskiego, z niewielkim lub żadnym komentarzem, także szersze objaśnienia, stając się świadectwem aktualizacji przekazu biblijnego. ${ }^{6}$

1 Tradycja ta została przyjęta także przez egzegetów chrześcijańskich.

2 Zob. np. sprzeczność między 2,2 a 7,4.

3 Np. w 11,9 pojawia się zachęta, by młodzieniec korzystał ze swych młodych lat, zażywając zabaw i uciech, co stoi w sprzeczności z biblijnym napomnieniem, by nie dać się sprowadzić na manowce własnym pożądaniom (por. Lb 15,39).

4 P. V. M. Flesher, The Wisdom of the Sage: Rabbinic Rewriting of Qohelet, 269-270.

5 S. C. Yesudian-Storfjell, The Reception of Qoheleth in a Selection of Rabbinic, Patristic and Nonconformist Test, rozprawa doktorska, Department of Biblical Studies, The University of Sheffield 2003.

6 Szerzej na ten temat zob. P. S. Alexander, Jewish Aramaic Translations of Hebrew Scriptures, w: Mikra, Text, Translation, Reading and Interpretation of the Hebrew Bible in Ancient Judaism and 


\section{1. Środowisko powstania i charakter Targumu Koheleta}

Podobnie jak w przypadku pozostałych Targumów do Pism nie da się dokładnie określić, kiedy i gdzie powstał Targum Koheleta ${ }^{7}$. Większość uczonych jest zgodna, że Tg Koh pochodzi z Palestyny. Jego język nie jest jednak czystym aramejskim dialektem palestyńskim, lecz był poprawiony przez skrybów i kopistów, którzy lepiej znali język Targumu Onkelosa i Talmudu Babilońskiego. Zdaniem E. Levine aramejska wersja Koheleta stanowi część tradycji literackiej faryzejsko-rabinicznej charakteryzującej się wykluczaniem tej księgi, cenzurowaniem jej i formułowaniem przeciw niej polemik ${ }^{8}$. Przyjmuje się, że tekst został napisany we wschodniej części basenu Morza Śródziemnego, między VI a IX w. ${ }^{9} \mathrm{O}$ istnieniu Targumu Koheleta wspominają Sheiltot ${ }^{10} \mathrm{z}$ VIII w. i Pesiqta Rabbati ${ }^{11} \mathrm{z}$ IX w., dlatego też wydaje się dość prawdopodobne, że Tg Koh może pochodzić właśnie $z$ tego okresu ${ }^{12}$. W tradycji liturgicznej Księga Koheleta jest odczytywana w czasie Święta Namiotów (Sukkot), lub w ósmym dniu święta,

Early Christianity, M.J. Mulder (ed.), 225-229; A. Kuśmirek, Starożytne żydowskie przekłady Biblii hebrajskiej i ich status we wczesnym judaizmie, 200-205.

7 Po raz pierwszy został opublikowany przez Bomberga w Biblia Rabinica w Wenecji w 1517 r. Od tego czasu przedrukowywany był wiele razy, lecz w kolejnych edycjach mnożyły się liczne błędy. Dlatego w 1873 r. Paul de Lagarde w swym dziele Hagiographa Chaldaice na nowo opracował spółgłoskowy tekst editio princeps. W 1905 r. A. Levy przygotował krytyczne wydanie Tg Koh: Das Targum zu Kohelet nach sudarabischen Handschriften herausgegeben. W 1968 r. A. Sperber w swojej The Bible in Aramaic IVA zawarł rękopis 2375 ze zbiorów Muzeum Brytyjskiego, a w 1978 r. E. Levine w swojej The Aramaic Version of Qohelet opublikował watykański rękopis Urb. Ebr. 1. Natomiast w 1987 r. L. Dîez Merino, L. wydał Targum de Qohelet. Edición Principe del Ms. Villa-Amil No 5 de Alfonso de Zamora. P. S. Knobel, Targum of Qohelet, 3.

8 E. Levine, The Aramaic Version of Qohelet, 68; Tak samo F. Manns, Le Targum de Qohelet, 180.

9 Powstanie Tg Koh Levine (The Aramaic Version of Qohelet, 68-69) ustala terminus a quo na 500 r., a terminus ad quem na $1101 \mathrm{r}$.

10 Achai z Szabha ( VIII w) był talmudystą babilońskim, lecz wspomniany traktat Sheiltot („Pytania”) napisał prawdopodobnie w Palestynie. Dzieło to powstało na podstawie nauk biblijnych i rabinicznych, i przeznaczone było dla pobożnych świeckich. Kładło nacisk na powinności moralne człowieka wierzącego, a uporządkowane było zgodnie z cotygodniowym cyklem lekcjonarzowym.

11 Dzieło to stanowi przykład rozprawy filozoficznej, w której poszczególne zagadnienia ułożone są w kolejności tematycznej, a nie egzegetycznej.

12 Przegląd hipotez na temat datacji Tg Koh, zob. P. S. Knobel, Targum of Qohelet, 14-15. 
gdy ten zbiegał się z szabatem - poświadczają to dopiero dokumenty od XI w., nie ma natomiast świadectw starszych ${ }^{13}$.

Proces narastania materiału wpisuje się w sposób przekazywania tradycji egzegetycznych, to jest przekaz drogą ustną, a następnie pisemną we wczesnym judaizmie rabinicznym. Pierwsza z nich była realizowana przez nauczanie, studium i dyskusje w szkołach i synagogach. Synagoga pozostawała najważniejszym miejscem odczytywania i zgłębiania Tory ${ }^{14}$. Targumy ukazują zatem dynamiczną relację między tekstem, synagogą i rozwojem egzegezy rabinicznej, potwierdzają również tezę, że zawierały one część Prawa przekazywanego drogą ustną ${ }^{15}$, które następnie zostały spisane. Zawierają zatem różne tradycje i idee, które zrodziły się na poszczególnych etapach procesu ich powstawania.

W Targumie Koheleta targumiści starali się pogodzić ze sobą teologię biblijną i rabiniczną. W tym celu stosowali wypracowane przez rabinów kategorie dosłowności (peszat) i alegorii (derasz). Targum Koheleta stanowi zatem świadectwo systematycznej, rabinicznej relektury księgi biblijnej, dzięki której została zaakceptowana i znalazła miejsce w kanonie (m. Yad. 3,5). Wśród wszystkich targumów Tg Koh i inne targumy do Pism zawierają najwięcej elementów midraszowych ${ }^{16}$.

Wydaje się, że odbiorcami Tg Koh mogli być uczestnicy spotkań odbywających się w szkołach i synagogach. Targum Koheleta był dla nich swego rodzaju midraszem homiletycznym, a jednocześnie przykładem, jak z tekstem biblijnym

13 Związek Koh ze świętem Szałasów nie jest łatwy do uchwycenia, inaczej niż każdy z pozostałych Pięciu Zwojów: Pnp odczytuje się na święto Przaśników obchodzone na wiosnę, gdyż według tradycji rabinicznej w. 1,9 mówi o Wyjściu z Egiptu, Rt odczytuje się w Szawuot, ponieważ opisywane w niej wydarzenia rozgrywają się podczas żniw jęczmienia, a nawrócenie Rut interpretowane jest na zasadzie analogii z przekazaniem Tory na Synaju. Est opowiada dzieje Purim, a Lm zawiera utwory żałobne, napisane po zburzeniu świątyni i upadku Jerozolimy w 587 r. przed Chr. P. S. Knobel, Targum of Qohelet, 4-5.

14 M. S. Wróbel, Wprowadzenie do Biblii Aramejskiej, 111-129.

15 Liturgiczne odczytywanie Pisma Świętego w synagodze doprowadziło do powstania całego zbioru przepisów regulujących proces translacji. Jak czytamy w m. Meg. 4,4: „Odczytujący Torę nie może odczytać mniej niż trzy wersy. Meturgeman może odczytać za jednym razem nie więcej niż jeden wiersz, a jeśli odczytuje [fragment z] Proroków, nie więcej niż trzy wiersze. Jeśli tworzą one odrębne sekcje, ma je odczytać jedna za drugą”. Z opisów Miszny wynika, że do zadań translatora należało też przekazanie tradycyjnej interpretacji tekstu. Istnienie cenzury potwierdza m. Meg. 4,9, które wskazuje, jak należy tłumaczyć Kpł 18,21.

16 J. Riber-Florit. Hagiographa, Targum to, w: J. Neusner, A. J. Avery-Peck, Encyclopaedia of Midrash. Biblical Interpretation in Formative Judism, vol. 1, 152-153. 
łączyć teologię rabiniczną. Zakładana późna data powstania Tg Koh świadczyłaby o tym, że stworzenie tego przekładu wynikało nie tyle z potrzeb liturgicznych, ile stanowiło kolejną próbę dopasowania tej księgi do teologii rabinicznej - jest to bardziej przykład eisegezy literackiej, to jest wprowadzania własnych idei do tekstów biblijnych, niż tłumaczenia przeznaczonego dla szerokiego kręgu czytelników.

Wyzwania hermeneutyczne, jakie Księga Koheleta stawiała przed tłumaczami, wśród wielu innych kwestii obejmowały m.in. postać autora, to jest Salomona, brak implikacji profetycznych, problem niesprawiedliwości na świecie, kwestię życia po śmierci czy brak podkreślania fundamentalnego znaczenia Tory. Targum rozpatruje te zagadnienia przez pryzmat własnej recepcji Koheleta księga przechodzi tu zmianę paradygmatu. Punktem centralnym omawianych tematów staje się właśnie postać Salomona. W Tg Koh raz po raz powraca tradycja mówiąca o Salomonie jako proroku i autorze tej księgi.

\section{Prorocki charakter wypowiedzi Salomona w Targumie Koheleta}

Tradycyjne utożsamianie Koheleta z królem Salomonem, jednocześnie uznanie go za autora tego tekstu wynikało $\mathrm{z}$ informacji podanych na początku księgi biblijnej. Kohelet przedstawia się jako „syn Dawida $(1,1)$, a następnie mówi o sobie: „Ja, Kohelet, byłem królem nad Izraelem w Jerozolimie” $(1,12)$. W biblijnej prezentacji Koheleta można dostrzec obraz postaci mędrca. Taka autoprezentacja była problematyczna zarówno sama w sobie, jak i w kontekście całego orędzia autora. Wspomniane $\mathrm{z}$ tego powodu też trudności z uznaniem autorytetu Księgi Koheleta, podobnie jak rabini, spróbował rozwiązać również targumista, przypisując Koheletowi-Salomonowi rolę prorocką, zmieniając tekst oryginalny tak, aby przypisać Koheletowi funkcję bardziej autorytatywną. Z tego powodu Tg Koh rozpoczyna się tytułem:

„Słowa proroctwa ${ }^{17}$ (האובן), jakie prorokował (יבנתיאז) Kohelet, [tj.] Salomon, syn Dawida, króla, który był w Jerozolimie" (Tg Koh 1,1$)^{18}$.

17 Kursywą zaznaczono słowa dodane w Tg Koh do tekstu hebrajskiego.

18 Przekład własny na podstawie tekstu mss Paris 110 opracowanego przez E. Clarke, po korekcie przez J. Lund i udostępnionego w programie BibleWorks 10 for Windows, BibleWorks LLC, Norfolk 2018. 
Wprowadzone przez aramejskiego tłumacza dodatki do tekstu biblijnego nie tylko utożsamiają w sposób bezpośredni Koheleta z Salomonem, lecz także dwukrotnie podkreślają prorocki charakter przekazu Koheleta ${ }^{19}$ za pomocą rdzenia יבנ. Najpierw jest on użyty w odniesieniu do słów, które będzie przekazywał Kohelet-Solomon, a następnie jako czasownik oddający czynność prorokowania.

\section{a) Proroctwa Salomona dotyczące przyszłości Izraela}

Targum Koheleta nie tylko przedstawia Salomona jako proroka, lecz także podaje treść głoszonych przez niego proroctw, które odpowiadają ważnym wydarzeniom $\mathrm{z}$ historii Izraela. Według targumu Salomon otrzymał wizje dotyczące przyszłości władców i królestwa Izraela.

Tg Koh 1,1 stanowi wprowadzenie do pierwszej wizji. W 1,2 zostaje ukazana treść proroctwa:

Kiedy Salomon, król Izraela, zobaczył (האובו) przez ducha prorockiego (האורל), że królestwo jego syna Roboama zostanie podzielone [między niego a] Jeroboama, syna Nabota, i że Jerozolima i świątynia zostaną zniszczone, a lud domu Izraela pójdzie na wygnanie, powiedział do siebie: „Marnością nad marnościami jest ten świat. Marnością nad marnościami jest wszystko, co ja i Dawid mój ojciec staraliśmy się zrobić. Wszystko to jest marnością".

Targumista konsekwentnie dodaje do tekstu biblijnego treść prorockiej wizji Salomona, który przepowiada przyszły podział królestwa pod rządami Roboama oraz zniszczenie Jerozolimy i świątyni przez Babilończyków oraz deportację narodu wybranego. W interpretacji targumu to właśnie proroctwo dotyczące wizji przyszłości jego królestwa powoduje, że Kohelet wypowiada słynne słowa: „Marność nad marnościami” (aram. וילבה לבאן) wskazując na bezowocne starania zarówno Salomona, jak i Dawida. Uniwersalna marność czy też próżność życia na tym świecie została przekształcona przez targumistę w specyficzną przyczy-

19 KohR 1,1.2 również nazywa Salomona prorokiem: „A on (Salomon) prorokował o królach domu Dawida, przewidzianych do rządzenia na tym świecie i w przyszłym świecie Mesjasza” (por. Tg 1 Krl 6,3).

${ }^{20}$ W Tg Koh użyto tego samego słowa, co w tekście hebrajskim w stopniu najwyższym, które można też przetłumaczyć jako „Największą próżnością” lub „Ulotne, jakże ulotne” (Biblia Ekumeniczna). 
nę i skutek. Starania Salomona i jego ojca, którzy swoje panowanie poświęcili dla zbudowania silnego państwa, zostaną zniweczone. Wypowiadając te słowa targumista dodaje aramejski zwrot הירמימב רמא, którego odpowiednika nie ma w tekście hebrajskim w. 1,2. Levine tłumaczy go jako „powiedział przez słowo boskie” („he said by divine word”), taka interpretacja wynika z użycia terminu Memra, które jest oddawane jako „Słowo JHWH”. Natomiast Knobel wskazuje, że chodzi tu raczej o literalne tłumaczenie, tj. „powiedział w swym mówieniu” (הירמימב רמא, zob. też 1,2; 8,17; 12,8), rozumianym jako „powiedział do siebie”. Powołuje się przy tym na inne fragmenty Koh, w których ma miejsce wypowiedź w pierwszej osobie dosł. „powiedziałem w mówieniu moim” (ירמימב תירמאן, zob. $2,1 ; 6,3 ; 7,23 ; 8,14 ; 9,16)$. Sformułowania te mają swoje odpowiedniki w hebrajskich zwrotach „powiedziałem w sercu moim” (hebr.בלב ינא יתרמא, np. 2,1) czy też „powiedział w sercu swoim”. Istotną zmianą wprowadzoną przez targumistę w odniesieniu do Salomona jest opis tego, co zostało mu to ukazane „przez ducha prorockiego" (האובנ חורל). Określenie to akcentuje natchnienie mówcy. Knobel przyjmuje w swoim przekładzie inną lekcję, mianowicie „przez ducha świętego" (אשדק חורל). Oba sformułowania występują w Tg Koh. Salomon działa pod natchnieniem „ducha prorockiego” (por. Tg Koh 1,4; 3,11.14; 4,15; 9,7.10), ale także „ducha świętego" $(8,12.14)$.

Wizję odwołującą się do przyszłości królestwa Salomona i dalszym losie jego syna przekazuje także Tg Koh 4,15:

Prorok Salomon (אייבנ המלשֶ) powiedział „Zobaczyłem przez ducha proroctwa od Pana (יי מדק־ן האובנ חורב), zobaczyłem wszystkich żyjących, którzy w swej głupocie zbuntują się przeciw memu synowi Roboamowi pod słońcem i podzielą królestwo, tak że zostanie przekazane Jeroboamowi”. Ale serce plemion Beniamina i Judy w całości jest $\mathrm{z}$ tym młodzieńcem, Roboamem, moim synem, który był drugi w mym królestwie, powstanie i będzie rządził w miejscu jego dziedzictwa, w Jerozolimie (Tg Koh 4,15).

Targumista ponownie nawiązuje do buntu plemion przeciw Roboamowi. Enigmatyczna wzmianka na temat poparcia chłopca, który miał być następcą władcy z tekstu biblijnego zostaje skonkretyzowana jako odpowiednik wydarzeń za czasów Roboama. W wypowiedzi Salomona targumista podaje negatywną ocenę tych, którzy stanęli po stronie Jeroboama, a pozytywnie ocenia plemiona Beniamina i Judy, zapowiadając rządy syna Salomona w Jerozolimie. Podobnie jak wcześniej Salomon głosi swoje wizje pod natchnieniem „ducha proroctwa” - 
jednak tym razem targumista wzmacnia to sformułowanie, dodając, że pochodzi ono „od Pana” (dosł. „sprzed JJJ” - ייי מדק־ץ).

Do tych wydarzeń nawiązuje także dodatek wprowadzony do tekstu biblijnego w Tg Koh 3,15:

Król Salomon powiedział przez ducha prorockiego (האובנ חורל): ,Pan wszystko uczynił w właściwie w swoim czasie. Doszło do walki za Jeroboama, syna Nabota, a nie za Szeby, syna Bichriego, lecz została opóźniona do czasów Jeroboama, syna Nabota, ponieważ gdyby była za Szeby, syna Bichriego, nie zostałaby zbudowana świątynia z powodu złotych cielców, które zrobił grzesznik Jeroboam i ustawił w Betel i Dan. I wyznaczył strażników na drogach, aby uniemożliwiali pielgrzymowanie. $Z$ tego powodu opóźniło się, aż świątynia została zbudowana, aby synowie Izraela nie zwlekali jej budową. Ukrył też przed nimi Wielkie Imię, zapisane i objaśnione na kamieniu węgielnym, gdyż znana Mu była zła skłonność, która była w ich sercach. Bo gdyby zostało człowiekowi powierzone, wykorzystałby je, aby odkryć przez Nie, co będzie na końcu czasów i na wieki. Dzień śmierci jest także ukryty przed nim, aby nie było znane [żadnemu] człowiekowi od początku, co stanie się na końcu.

Odpowiednikiem tekstu hebrajskiego w targumie jest zdanie: „Pan wszystko uczynił właściwie (dosł. „pięknie”) w swoim czasie”21. W Księdze Koheleta jest mowa, że to wszystko uczynił Bóg. Tłumacz aramejski wprowadza w tym miejscu, charakterystyczną dla targumów zmianę, zastępując ogólne określenie Bóg (מיהלאוi) imieniem własnym - JHWH (zapis aram. "י", w przekładzie Pan). W ten sposób odbiorcy otrzymali pewność, że sprawcą działania był sam JHWH. Ponadto swój odpowiednik w tekście hebrajskim ma wzmianka „ich sercach” oraz fragment o tym, że człowiek ma trudności z poznaniem tego, co było na początku i co jest na końcu, jednak te wyrażenie są użyte w innym kontekście niż w tekście hebrajskim.

Targumista wprowadza także do tekstu biblijnego osoby i wydarzenia znane z literatury rabinicznej, które mogły mieć związek z przedstawianymi wydarzeniami. Tutaj taką postacią jest Szeba, syn Bichriego, który był ojcem Jeroboama (b. San. 101b) ${ }^{22}$. Targumista podkreśla konieczność budowy świątyni, która miała

21 Tekst Koh 3,11 można przetłumaczyć: „Wszystko pięknie uczynił w swoim czasie, także wieczność (סלעה) włożył w ich serce, tak jednak, że człowiek nie zdoła pojąć dzieła, które uczynił Bóg od początku do końca”.W miejsce „,wieczność” można też przetłumaczyć „świat”.

22 E. Levine, The Aramaic Version of Qohelet, 52. 
zastąpić bałwochwalcze sanktuaria w Betel i Dan. Następnie targumista dodaje legendę na temat kamienia węgielnego, na którym zostało wypisane „Wspaniałe Imię” (dosł. „Wielkie Imię” - אבר אמשֶ), jednak zostało ukryte przed ludzkością. Późniejsza tradycja z tym związana mówi o cudach, a także o możliwości przepowiadania przyszłości. W tym kontekście została włączona obecna w tradycji żydowskiej: nauka o złej skłonności (אשיב ארצי), z powodu której pewne sprawy zostały ukryte przed człowiekiem, między innymi wiedza o dniu śmierci danego człowieka oraz o tym, co się stanie na końcu dni ${ }^{23}$.

Salomon, natchniony duchem prorockim głosi też zagładę, która spotka Izraela. Hebrajski tekst Koh 10,7 przedstawia jedynie zmienny los, który może spotkać także władców za pomocą takiego obrazu: „Widziałem sługi na koniach, a książąt idących pieszo jak słudzy”. Targumista parafrazuje ten obraz, wskazując na zapowiedź klęski Izraela $\mathrm{z}$ ręki wrogów:

Tak powiedział Salomon, król Izraela w duchu proroctwa (האובנ חורל):,ZZobaczyłem, jak ludzie, którzy niegdyś byli niewolnikami ludu Izraela, wzrastają w siłę i jeżdżą na koniach jak władcy, natomiast lud Izraela i jego przywódcy chodzą po ziemi jak niewolnicy" (Tg Koh 10,7).

W targumie Salomon widzi to samo co Kohelet - targumista stara się zachować tu dosłowne znaczenie tekstu, ale jednocześnie chce nadać mu konkretny wymiar historyczny. Również Tg Koh 10,9 prezentuje Salomona jako proroka, który po raz kolejny opisuje klęski, jakie staną się udziałem Izraela:

Powiedział Salomon, prorok (אייבנ): ,Zostało mi objawione, że Manasses, syn Ezechiasza, będzie grzeszył i czcił wizerunki z kamienia. Dlatego zostanie wydany w ręce króla asyryjskiego, który zwiąże go sznurami, ponieważ zlekceważył słowa Tory, pierwotnie zapisane na kamiennych tablicach. Dlatego będzie za nie cierpieć. A Rabsak, jego brat, będzie czcił wizerunki z drewna i porzuci słowa Tory złożone $\mathrm{w}$ arce $\mathrm{z}$ drzewa akacjowego - dlatego zostanie spalony ogniem przez anioła Pana”.

Hebrajski tekst Koh 10,9 ma charakter przysłowia, opisuje wykonywanie prac, które mogą stać się niebezpieczne: „Kto rusza kamienie, może się o nie pokaleczyć, a kto rąbie drewno, naraża się przez nie na niebezpieczeństwo". I tym

23 Talmud głosił, że siedem rzeczy zostało zakrytych przed człowiekiem: dzień śmierci, dzień pocieszenia, głębia sądu, co jest w sercu bliźniego, na czym zarabia, kiedy ponownie nastanie dynastia Dawidowa, kiedy nadejdzie kres grzesznego królestwa (b. Pes. 54b). 
razem uniwersalny obraz z życia człowieka został wykorzystany przez targumistę jako pretekst do prezentacji tego, co zostało objawione prorokowi Salomonowi w odniesieniu do konkretnego wydarzenia z życia Manassesa (por. $2 \mathrm{Krl}$ 21; 2 Krn 33,7-11). Mamy tu podwójne odniesienie do kamieni, o których jest mowa w tekście biblijnym. Pierwsze z nich jest negatywne - kamienne wizerunki, którym władca oddawał cześć, a drugie odnosi się do kamiennych tablic, na których były zapisane słowa Prawa (אתירוא ימגתפ), którego nie zachowywał Manasses. Lekceważenie Tory stał się przyczyną jego klęski i wygnania. Wykonawcą tej kary był król asyryjski. Druga część powiedzenia w Tg Koh odnosi się do Rabsaka, który według tradycji talmudycznej był bratem Manassesa (b. Ber. 10b). Także on został ukazany jako czciciel drewnianych idoli. I w tym wypadku dostrzec można podwójne odniesienie do drewna i o karze za odrzucenie Tory, która znajdowała się w drewnianej arce. Tym razem kara była o wiele surowsza. Miał zostać spalony przez anioła Pana (ייד אכאלמן).

\section{b) Słowa proroctwa Salomona na temat współczesnych mu czasów}

Kilka fragmentów Tg Koh, w których targumista przypisuje Salomonowi ducha proroctwa, dotyczy nie tyle wizji przyszłości, co spraw mu współczesnych i stanowi krytykę bezprawia szerzącego się w życiu społecznym i religijnym. Salomon pod wpływem ducha proroctwa wypowiada się między innymi o sprawiedliwych i grzesznikach, o dobru i złu, Prawie, mądrości:

Zobaczyłem przez ducha prorockiego (האובנ חורל), że mądrość ma przewagę nad głupotą, jak światłość dnia ma przewagę nad ciemnością nocy. (Tg Koh 2,13).

Wczesna nauka rabiniczna utożsamiała mądrość z Torą - fakt, że targumista łączy ją z proroctwem, może odzwierciedlać głębszą potrzebę eschatologizacji tłumaczonego tekstu przy jednoczesnym pragnieniu zachowania peszat wersji hebrajskiej ${ }^{24}$. Umiejętność rozróżniania między dobrem i złem oraz między sprawiedliwym i grzesznikiem stanowi cnotę, z którą targumista chętnie się utożsamia - duchowi proroctwa przypisuje się tu konkretną rolę może właśnie po to, aby podkreślić ważność i znaczenie tej umiejętności.

24 S. C. Yesudian-Storfjell, The Reception of Qoheleth, 68. 
Król Salomon rzekł przez ducha proroctwa (האובנ חורל): „Dobre pokolenie sprawiedliwych odchodzi z tego świata przez grzechy złego pokolenia grzeszników, którzy przyjdą po nich ${ }^{25}$. Ale ziemia trwa na wieki, by ponieść karę, która przychodzi na ten świat z powodu grzechów ludzi”. (Tg Koh 1,4).

Wyjaśnianie i konkretyzowanie ogólnikowych i najwyraźniej dwuznacznych wypowiedzi Koheleta o naturze człowieka, i o nadchodzącej karze stanowi świadome i celowe działanie targumistów.

W Tg Koh 9,7 dokonują ponownej eschatologizacji tekstu ${ }^{26}$, a w rozszerzeniach i dodatkach stawiają sprawiedliwych w uprzywilejowanej pozycji:

Salomon powiedział przez ducha proroctwa od Pana (יי מדק־ןמ האובנ חורל): „Do każdego sprawiedliwego Pan Wszechświata zwróci się indywidualnie: «Idź, w radości spożywaj swój chleb, który został ci dany ze względu na chleb, którym ty dałeś biedakom i potrzebującym, którzy byli głodni, i w pokoju serca pij swe wino, ukryte dla ciebie w ogrodzie Eden ${ }^{27}$ w zamian za wino, które ty zmieszałeś dla biedaków i potrzebujących, którzy byli spragnieni». Twe dobre uczynki zostały już przyjęte przez Pana. (Tg Koh 9,7).

Wiersze poprzedzające ten fragment są w biblijnej Księdze Koheleta skrajnie pesymistycznie i fatalistyczne. Autor stwierdza w nich najpierw, że ten sam los spotyka wszystkich, zarówno sprawiedliwych, jak i grzeszników. W dalszej części wskazuje jednak na przewagę bycia żywym nad umarłym. Z tekstu hebrajskiego nie wynika, do kogo Kohelet kieruje swe słowa. Natomiast targumista jasno określa, komu Pan okaże swoją łaskę. Wzmianka o duchu proroctwa wzmacnia wymowę tego stwierdzenia, uzasadnia w jaki sposób Salomonma możliwość spojrzenia w przyszłe życie i nabrania pewności co do nagrody przygotowanej dla sprawiedliwych. Cechą wyróżniającą człowieka sprawiedliwego jest zachowywanie Prawa - targumista po raz kolejny podkreśla, że Salomon może poznać tę prawdę dzięki duchowi proroctwa:

25 Por. b. B.Q. 60a: „To jest dobro dla niego, jak powiedziano: «Sprawiedliwy będzie zabrany z powodu zła, które przyjdzie» (Iz 57,1)”. A zatem sprawiedliwy nie zobaczy grzeszników, którzy zostaną ukarani.

26 S. C. Yesudian-Storfjell, The Reception of Qoheleth, 69.

27 Por. b. San. 99a i b. Ber. 34b. 
Król Salomon rzekł: „Wiem dzięki duchowi proroctwa (האובנ חורל), że nie ma dla nich, dla ludzi, nic dobrego poza tym, żeby cieszyli się radością Tory i czynili dobro za dni swego życia (Tg Koh 3,12).

Przepracowując tekst Koh 3,12: „Poznałem więc, że dla ludzi nie ma nic lepszego, jak tylko radować się i używać, póki żyją", targumista modyfikuje wypowiedź autora biblijnego o radościach człowieka. Tam gdzie Kohelet mówi o ludziach, nie tylko o sprawiedliwych, targumista zmienia wymowę tekstu i wstawia do przekładu znaczenie dodane, które radykalnie zmienia jego wydźwięk, i to do tego stopnia, że przekład ten trudno nawet uznać za tłumaczenie wersji oryginalnej. Podobnie jak w innych targumach synowie ludzcy swe najgłębsze spełnienie znajdują w Prawie, a nie w osobistych przyjemnościach - Salomon przekonuje się o tej prawdzie znów dzięki duchowi proroctwa.

$\mathrm{W}$ targumie przepowiadanie $\mathrm{w}$ duchu proroctwa zostało użyte również w kontekście teraźniejszości, a dokładniej w odniesieniu do sposobu sprawowania sądów przez Salomona:

Król Salomon zwany Koheletem starał się w swej mądrości sądzić ludzi zgodnie z wyobrażeniami swego serca i bez świadków. Dlatego przez ducha proroctwa od Pana (יי בדק־ןמ האובנ חורל) powiedział mu tak: „Zapisane to już zostało w Torze przez Mojżesza, nauczyciela Izraela, że słowa są słuszne i prawdziwe: «Sprawa winna być rozstrzygnięta na podstawie słowa świadków»” (Tg Koh 12,10).

Przytoczony wyżej cytat jest parafrazą Koh 12,10: „Starał się Kohelet znaleźć słowa zachwytu i napisać słuszne słowa prawdy (תמשד רשי בותכו ץפח־ירבז) תמא (ת)". W tekście biblijnym jest tylko mowa o słowach, których autor księgi poszukiwał (שקב), aby wyrazić swoje myśli w sposób prosty, rzetelny i prawdziwy. Targum wychodzi od tego końcowego sformułowania i rozbudowuje go parafrazą na temat procedury prowadzenia procesów sądowych i zeznań świadków (Pwt 9,15). Zarówno Tg Koh, jak i Talmud interpretują ten wiersz w podobny sposób: „«Kohelet starał się znaleźć słowa zachwytu» - Kohelet próbował obwieścić wyroki na podstawie własnego oglądu spraw bez świadków i bez ostrzeżenia, na co pojawił się głos z nieba (לוֹק תב) i powiedział, jak napisano: «Słowa są słuszne i prawdziwe» $(12,10)$, co oznacza «na podstawie dwóch świadków» (Pwt 19,15)" (b. RoszH. 21b). Różnica polega na tym, że targum nie mówi o warunku dotyczącym wcześniejszego ostrzeżenia i używa wyrażenia „duch prorocki od Pana”, a nie tak jak w Talmudzie „niebiański głos”, 
czy też „głos z nieba” (לוֹק תב (ל) ${ }^{28}$. Nawet najmądrzejszy z ludzi nie powinien sądzić w oparciu tylko o posiadaną wiedzę, lecz winien korzystać z pomocy odzywającego się w nim głosu Boga, bo jedynie On jest w posiadaniu całej prawdy. Żaden ziemski sąd, bez względu na to jak byłby mądry, w oparciu o własne tylko starania, a bez odwoływania się do pomocy Bożej, nie jest w stanie wydać doskonałego werdyktu ${ }^{29}$.

\section{Proroctwa Koheleta jako element przesłania teologicznego Tg Koh}

Wymienione w poprzednich paragrafach fragmenty Tg Koh, w których występuje wyrażenie „duch proroctwa” nie mają swojego odpowiednika. W biblijnej Księdze Koheleta nie ma jakiejkolwiek wzmianki o proroctwie czy nawet jakiejś sugestii o proroctwie, stąd tym wyraźniej widać $\mathrm{w}$ targumie przedstawienie Salomona w randze prorockiej. Wyrażenia tego nie można odnaleźć nie tylko w tekście hebrajskim, lecz także w innych tekstach Biblii Hebrajskiej. W tekstach biblijnych wielokrotnie jest mowa o „duchu Pańskim”30, czy też „duchu Bożym”31, ale nie o „duchu proroctwa”.

Prorocki język Targumu Koheleta odpowiada literackiej tradycji rabinicznej związanej z Salomonem. Zawarte w targumie krótkie wzmianki i aluzje mają charakter midraszowy. Mogą one także świadczyć o tym, że targumista zakładał

28 Dosł. לוֹ - „Córka głosu”, „echo”. Por. np. TgN Rdz 22,10; 27,33; 38:25; Lb 21,6; TgPsJ Pwt 29,15.

29 Por. 1 Krl 3,27b, gdzie mowa jest o słynnym rozstrzygnięciu Salomona dotyczącym dwóch kobiet, z których każda twierdziła, iż jest matką nowonarodzonego dziecka. O ile TM konkluduje po prostu: „Ta jest jego matką”, o tyle niektóre wersje TJ nie chcąc pozwolić na to, by nawet król Salomon wyrażał stwierdzenie tak kategoryczne i jednoznaczne bez urzędowego dowodu, przekazuje interpretację homiletyczną: „A z niebios dało się słyszeć echo głosu niebiańskiego, który mówił: 'Ta jest jego matką?". W podobnym duchu wypowiada się midrasz: „I krzyczał duch święty: «Ta jest jego matką»”. Ten sam midrasz ostro krytykuje Salomona za jego niekonwencjonalną i potencjalnie niebezpieczną metodę rozwiązania postawionego problemu: „R. Judah rzekł w imię R. Elai: «Gdybym ja tam był, wokół szyi Salomona zawiązałbym wełnianą linę. A on powiedział: Przynieście mi miecz! (1 Krl 3,24a) - gdyby matka nie była pełna litości dla dziecka, to na pewno zostałoby zabite»”.

30 Zob. Sdz 3,7; 1 Sm 9,27; 1 Krl 18,12.

31 Zob. Rdz 41,38; Lb 24,1; Hi 27,3. 
znajomość zachowanego midraszu przez czytelnika, czy też słuchacza ${ }^{32}$. Przeprowadzone badania lingwistyczne i egzegetyczne dowiodły, że pod względem językowym oraz treści Tg Koh wykazuje stopniowe narastanie materiału ${ }^{33}$.

$\mathrm{Z}$ tego względu przypuszcza się, że użycie wyrażenia „duch prorocki” w Tg Koh, i to w tak wielu miejscach, zostało wprowadzone na etapie wczesnego judaizmu rabinicznego. W judaizmie klasycznym spotykany jest termin „duch święty” używany w odniesieniu do ducha proroctwa i wiąże się przede wszystkim z działalnością proroków ${ }^{34}$. W pewnym sensie wyrażeniu ,głos z nieba” (תַ) לוֹ) odpowiada określenie „duch święty” ${ }^{35}$, które było używane, wtedy, gdy Bóg objawiał swoją wolę człowiekowi, lub jako kontynuacja Boskiego działania po tym, jak wierzono, że duch święty przestał działać z Izraelem (por. Yoma 9b: „po śmierci ostatnich Proroków duch święty został zabrany od Izraela, ale lud nadal korzystał z głosu z nieba (לוֹק תב). W teologii rabinicznej pojęcie „duch święty” oznacza inną manifestację Boga.

W Tg Koh „duch prorocki”, czy też „duch święty” obdarza Salomona władzą i wiarą. W wyniku przepracowania Księgi Koheleta przez rabinów wypowiedzi autora biblijnego miały być odczytywane jako słowa Salomona. Warto zauważyć, że o ile w tekście hebrajskim Salomon sam jest w stanie dostrzec, jakie korzyści płyną z posiadania mądrości, to według targumu wiedzę tę zdobywa dzięki duchowi proroctwa.

Wprawdzie tradycja literacka o Salomonie jako proroku nie jest w Tg Koh czymś nowym, to jednak częstotliwość, z jaką motyw ten tu się pojawia, jest wyjątkowa. Okazuje się, że targumiści próbują zmierzyć się z problematycznym przydomkiem Koheleta, zwanego też Eklezjastem. Choć był on utożsamiany z Salomonem, to jednak w tekście hebrajskim brakuje wyraźnej identyfikacji i sprecyzowania pełnionej przez niego funkcji religijnej.

Należy podkreślić, że przypisywanie Salomonowi prerogatyw prorockich nie jest dziełem targumistów, z czymś podobnym mamy bowiem do czynienia w znacznie starszych pismach rabinicznych, z których zapewne tłumacz Tg Koh

32 Teksty te znajdują się konkretnie w GenR, ExodR, LevR, m. 'Abot, Tanhuma, Midrasz Shmuel, Pesiqta' Rabbati i na wielu innych miejscach literatury rabinicznej, z wyłączeniem najstarszych zachowanych tekstów, tj. Mekhilta', Sifre, Sifra.

33 E. Levine, The Aramaic Version of Qohelet, 52.

34 D. Patte, Early Jewish Hemeneutic in Palestine, 119.

35 Czy też „duch świętości”. Szerzej zob. M. S. Wróbel, Wprowadzenie do Biblii Aramejskiej, 243-256. 
zaczerpnął różne motywy i pojęcia. Talmud Babiloński (Sotah 48b) stawia Salomona w jednym rzędzie z Dawidem i Samuelem, nazywając ich "prorokami starszymi”. Podobne określenia można spotkać w Tg 1 Krl, który w 6,3 stwierdza: „On [Salomon] prorokował o królach z domu Dawida, którzy przeznaczeni zostali do rządzenia tym światem i przyszłym światem Mesjasza"36.

Prezentacja Salomona jako proroka stanowi istotny element przesłania teologicznego Tg Koh. Targumista rozwija tekst hebrajski w jego znaczeniu bezpośrednim i proponuje przekład interpretacyjny wzbogacony o szereg dodatków mających charakter midraszowy.

\section{Podsumowanie}

Na podstawie analizy tekstów, w których Kohelet-Salomon jest przedstawiony jako prorok można wskazać w jaki sposób targumista mierzy się z wyzwaniami hermeneutycznymi, które Księga Koheleta stawiała przed teologią rabiniczną oraz targumiczną. Aramejscy tłumacze rozwiązują je przez pryzmat własnej recepcji Koheleta, księga przechodzi tu zmianę paradygmatu, bo punktem centralnym i osią, wokół której obracają się omawiane tematy, staje się Salomon. Według wersji biblijnej ideałem człowieka jest postać filozofa-króla. Tymczasem według targumu takim ideałem jest pobożny i sprawiedliwy mędrzec, dbający o biednych, którego personifikuje prorok Salomon. Warto zauważyć, że w biblijnej księdze Salomon sam jest w stanie dostrzec, jakie korzyści płyną z posiadania mądrości, natomiast według targumistów wiedzę tę zdobywa właśnie dzięki duchowi proroctwa.

Proroctwa wypowiedziane przez Salomona w targumie dotyczą między innymi losów Izraela i jego władców. Wprowadzenie perspektywy prorockiej w kontekście losów Roboama, syna Salomona i podziału Izraela pozwala uwolnić od odpowiedzialności za te dramatyczne wydarzenia samego Salomona (por. 1 Krl 11,11-12), a dodatkowo umożliwia interpretację gorzkich słów Koheleta, dotyczących marności i niekonsekwencji życia. Interpretacja ta kieruje odbiorcę na los jednostki, a nie ogólnie ludzkości i znikomości życia. Taka recepcja tekstu biblijnego pozbawia go uniwersalizmu i ironii w odniesieniu do natury życia

36 Z podobnymi wypowiedziami o Salomonie jako proroku spotykamy się również w Tg Pnp (1,1.17; 7,2; 8,5.13). Zob. tłum. Tg Pnp: M. Baraniak, Zjawisko targumizacji na podstawie Targumu do Pieśni nad Pieśniami, 190-253. Salomon jest uznawany za proroka także w islamie. 
ludzkiego. Targumiści wielokrotnie zastępują ogólniki hebrajskie konkretami, odwołując się do postaci i wydarzeń historycznych.

Istotnym elementem przesłania Tg Koh, który dostrzec można w prorockich wypowiedziach Salomona, jest zbiór reguł postępowania, którymi powinni się kierować w życiu jemu współcześni. Zasady te głosili także rabini. Choć biblijny Kohelet przestrzegał przed "pisaniem wielu ksiąg” i studiowaniem zbyt długo (Koh 12,12), dla targumistów badanie Tory ma kluczowe znaczenie i nierozerwalnie jest związane zmajacym nadejść, spodziewanym nieuchronnym sądem na końcu czasów. Zaniechanie tego zajęcia uważano bowiem za grzech. Studium Tory nie tylko ma przynosić radość i stanowić już nagrodę na tym świecie (m.in. 2,10; 3,12; 8,15), ale także przymnażać zasług na życie wieczne (np. 5,11). Wprowadzając do tekstu biblijnego wypowiedzi prorockie Salomona na temat sądu i losu sprawiedliwych po śmierci w Tg Koh przesłanie Koheleta zyskuje wymiar eschatologiczny, którego brak w oryginale. $Z$ wyzwaniami jakie stawiała wersja hebrajska, targum radzi sobie w ten sposób, że konkretyzuje ogólne stwierdzenia Koheleta, a obrazowy język oryginału zastępuje wypowiedziami bardziej zrozumiałymi i odwołującymi się do spraw codziennych. Następuje tu zupełne odwrócenie perspektywy i znika kontrast dzielący indywidualną percepcję Koheleta od mądrości otrzymanej z góry. Targumiści przepracowali treść księgi biblijnej, przekształcając ją w treść odpowiadającą normatywnej teologii rabinicznej. Targum Koheleta odzwierciedla zatem teologię, hierarchię wartości i styl życia judaizmu rabinicznego.

\section{Bibliografia}

Alexander, P.S., Jewish Aramaic Translations of Hebrew Scriptures, w: Mikra, Text, Translation, Reading and Interpretation of the Hebrew Bible in Ancient Judaism and Early Christianity, M. J. Mulder (ed.), Van Gorcum. Assen/Maastricht, 1998, s. 217-253.

Baraniak, M., Zjawisko targumizacji na podstawie Targumu do Pieśni nad Pieśniami. Krytyczna edycja tekstu z manuskryptu M 1106 z analiza egzegetyczno-hermeneutyczna i ttumaczeniem, Dom Wydawniczy Elipsa, Warszawa 2013.

Díez Merino, L. (ed.), Targum de Qohelet. Edición Principe del Ms. Villa-Amil No 5 de Alfonso de Zamora (Biblioteca Hispana Biblica 13), Consejo Superior de Investigagiones Cientificas, Madrid 1987.

Flesher, P.V.M., The Wisdom of the Sages: Rabbinic Rewriting of Qohelet, w: Aramaic in Postbiblical Judaism and early Christianity: Papers from the 2004 National Endowment for the 
Humanities Summer Seminar at Duke University (Duke Judaic Studies 3), E.M. Meyers, P. V. M. Flesher (ed.),Eisenbrauns, Winona Lake 2010, s. 269-279.

Flesher, P.V.M. - Chilton, B., The Targums: A Critical Introduction, Baylor University Press, Waco 2011.

Grossfeld, B., (ed.), The Targum to the Five Megilloth, Hermon Press, New York 1973.

Knobel, P.S., Targum of Qohelet, w: The Aramaic Bible: The Targum of Job and The Targum of Proverbs and Targum of Qohelet, K. Carthcart, M. Maher, M. McNamara (ed.), (Aramaic Bible 15), The Liturgical Press, Collegeville 1991.

Kuśmirek, A., Starożytne żydowskie przekłady Biblii Hebrajskiej i ich status we wczesnym judaizmie, w: Wielkie Księgi Ludzkości, A. Czajka (red.), Wydawnictwo Uniwersytetu Kardynała Stefana Wyszyńskiego, Warszawa 2013, s. 193-205.

Levine, E., The Aramaic Version of Qohelet, Sepher-Hermon, New York 1981.

Levy, A., Das Targum zu Kohelet nach sudarabischen Handschriften, Breslau 1905; reprint Kessinger Publishing 2010.

Manns, F., Le Targum de Qohelet - Manuskrit Urbinati 1, Traduction et Commentaire, Liber Annuus 42 (1992), s. 145-198.

Neusner, J., Avery-Peck A.J., Encyclopaedia of Midrash. Biblical Interpretation in Formative Judism, Vol. 1-2, SBL Press, Atlanta 2005.

Patte, D., Early Jewish Hermeneutic in Palestine, Scholars Press, Missoula 1975.

Ribera-Florit, J., Hagiographa, Targum to, w: Encyclopaedia of Midrash. Biblical Interpretation in Formative Judism, J. Neusner, A.J. Avery-Peck, Vol. 1, SBL Press, Atlanta 2005, s. 152-153.

Sperber, A., The Bible in Aramaic, Vol. 4a: The Hagiographa, Brill, Leiden 1968.

Wróbel, M.S., Wprowadzenie do Biblii Aramejskiej, Wydawnictwo Archidiecezji Lubelskiej „Gaudium”, Lublin 2017.

Yesudian-Storfjell, S. C., The Reception of Qoheleth in a Selection of Rabbinic, Patristic and Nonconformist Test, rozprawa doktorska, Department of Biblical Studies, The University of Sheffield 2003. 